\title{
A Lexico-Pragmatic Interpretation of Peace in the 2013 Kenyan Presidential Campaign Speeches Regarding Conflict Management
}

\author{
Norah Mose', Benson Ojwang,2, Lilian Magonya ${ }^{3}$ \\ ${ }^{1}$ Department of Linguistics, Maseno University, Private Bag, Kisumu, Kenya \\ ${ }^{2,3}$ Faculty, Department of Linguistics, Maseno University Private Bag, Kisumu, Kenya
}

\begin{abstract}
Words have power to control human thoughts and behaviour. In a country like Kenya which has experienced election-related conflict since 1992, with the exception of 2013, various lexical choices, especially by the political class, have had varying implications to the electorate. The paper analyzed the lexico-pragmatic processes of interpreting the term peace employed in the 2013 presidential campaign speeches. The objective of the study was to establish the relevance of the concept peace employed in conflict management in the 2013 Kenyan presidential campaign speeches to the residents of Tarakwa in Uasin Gishu County, Kenya. Four presidential campaign speeches of 2013 with the content of peace were purposively sampled and reviewed by focus group discussion participants. Using analytical research design, data was interpreted qualitatively within the precincts of Dan Sperber and Dierdre Wilson (1995) relevance theory. The results reveal that the concept peace was narrowed to denote the need to desist from violence during the 2013 elections. At the same time, the concept peace was broadened and equated to love, unity, individual development and freedom. Looked at this way, the participants had expectations that the 2013 elections would be peaceful. However, they also abandoned these expectations because peace also denoted campaigning for oneself, celebrating victory in advance and making peace dependent on a candidate's victory. Thus, the concept peace employed in the presidential campaign speeches in regard to conflict management was relevant in some ways and irrelevant in others.
\end{abstract}

Keywords: Peace, Relevance, Lexical, Concepts, Ad Hoc Concept, Conflict, Conflict $\quad$ Management

\section{INTRODUCTION}

Politics, power and language are inextricable. Through various lexical choices, during election campaigns, politicians struggle for power in order to make decisions, to control resources, to control other people's behaviour and often to control their values (Thomas \& Wareing, [1]). Lexical choices consist of a whole range of the lexicon (Haegeman, [2]). The lexicon or "dictionary" deals with lexical items of the language; that is, lexemes or words that make up its vocabulary (Huddlestone, [3]). According to Crystal [4], lexical item or lexeme refers to a unit of lexical meaning which exists regardless of any inflectional endings it may have or the number of words it may contain; thus "fibrillate", "rain cats and dogs", and "come in" are all lexemes".

The analysis of the lexical choices denoting peace in the 2013 presidential campaign speeches in this paper was intertwined with the variables "conflict" and "conflict management". Persaud and Turner [5:p417] define conflict as "disagreement between two or more parties in which one perceive(s) a denial of a right, resources, or absence of capacity to obtain justice which leads to anger, hurt, hate and possibly verbal and violent actions and reactions resulting in damage to person(s), emotionally and physically and/or property". Conflict resolution entails a short-term phenomenon that can be resolved permanently, while in conflict management the goal is to reduce or control conflict volatility (Shinar, [6]). To describe conflict management or conflict resolution, reference is always made to conflict (Burnes, [7]).

In Kenya, election-related conflict has been grounded in the notion of "us" and "them" in terms of political gains aligned in ethnocentric politics. Yieke [8] points out that the political and economic power in Kenya has been vested in trusted circles of the presidents' ethnic elites since independence in 1963. Consequently, there have been political contestations aimed at retaining the political and economic power or jostling it from those who have it. Jenkins [9] argues that this has led to electionrelated violence of varying magnitudes since the advent of multiparty elections in 1992. Owino [10: 
p63] defines electoral violence as "acts that seek to determine, delay, or otherwise influence an electoral process through violence, assault, thuggery and intimidation amongst other negative political behaviours. Owino [2013: p63] adds that the violence may manifest during pre-election, election and post-election stage and can be either physical or psychological dimension or both" [sic]. According to Yieke [8], the proximate causes of conflict are intrinsically related to democratization and electoral cycle and so as multi-partyism became increasingly probable in the 1990 s, senior politicians in many political rallies issued inflammatory statements and utterances asking for people to go back to their ancestral lands or they be forced out. Vernacular radio stations, Short Messaging Services (SMS), and print media were vehicles for relaying inflammatory statements enmasse. In such statements and utterances words including "insiders" and "outsiders", "foreigners" or "the immigrant guest" fanned election-related violence (Hirsch, [11];Jenkins, [9]).

Siele [12] samples the word "thief" which stereotypically portrayed the Kikuyu ${ }^{11}$, an ethnic group originally from Central Kenya. The Kikuyu have spread throughout the country and have acquired land and other property. The flip side of it is that people associate them with land grabbing, especially in the Rift Valley, where people believe that Jomo Kenyatta, the first president of Kenya, irregularly allocated them land meant for the Kalenjin (Michira, [13]). Also their aggression in business make people think they make profit through underhand deals. As such most vernacular radio stations had a term referring to the Kikuyu as chorik, among the Kalenjin ${ }^{22}$ and jokuoye among the Luo ${ }^{33}$. Conversely, the term "uncircumcised" referred to the members of the Luo, who do not practise circumcision to initiate the youth into adulthood, to portray them as children and premature (Siele, [12]). Words like kihii, ng'etiek and abaisia were stereotypically used by the Kikuyu, Kalenjin and Abagusii ${ }^{44}$ respectively to refer to the Luo.

Apart from stereotypes, coded expressions such as "beasts" and "weeds" were used by politicians to instill to the listener the notion of the "other" as people belonging to minority indigenous ethnic groups and asked the majority to arm and protect themselves (Yieke, [8]). It is also alleged that some radio stations enabled individuals to make unregulated hateful statement which encouraged the listeners to respond by exhibiting violent behaviour (Yieke, [8]). Use of hate speech was not limited to politicians as church priest also perpetrated violence during their sermons. Yieke [8] observes that one priest referred to one presidential candidateas the devil himself and wondered how such a person could lead the country and yet he did not even have a Christian name.

During the 2007/2008 post-election violence, the disputed presidential results preceded Short Messaging Services (SMSs) that were used to spread rumours and inflammatory speech that encouraged revenge, attacks and even arming of militia groups. Lexical items with meanings shared among the majority communities were used as codes referring to other ethnic groups that were marked for eviction. Sangari "coach grass", derived from Kalenjin referred to the Kikuyu's penetration in the Rift Valley, who like the couch grass that had deeply entrenched roots had to be uprooted. Madoadoa "spots", a Kiswahili word, complemented sangari in the way the Kalenjin wanted to "cleanse" the Rift Valley by erasing traces of the Kikuyu. The Kikuyu on their side referred to the Kalenjin as ngui "dog" (Yieke, [8]; Njogu, [14]). While these lexical items had the impact of igniting violence, Ojwang' [15] points out the print media initially adopted a pessimistic description of the 2007 elections as depicted by words such as bungled, stolen, marred, chaotic and bloody. Such a pessimistic tone fanned the 2007/2008 post-election violence and the standard language of reporting the protracted violence was synonymous with terms such as violence, chaos, skirmishes and bloodletting (Ojwang', [15]). The later phases of reporting, Ojwang' [15] argues showed concern to deaths with questions suggesting an end to violence taking the headlines. This way, Ojwang' [15] observes that the media reflects public sentiments by being the mouth piece of the masses.

Acknowledging the role of the vernacular radio stations, print media and SMS in exacerbating conflict, the government reminded people about the consequences of hate speech and increased peace messaging instead in the run up to 2013 general elections (Halakhe, [16]). On diplomatic fronts, Cho, Conners, Fatima and Yalim [17] note that strategic political messaging like Obama's "take it to the court" and intensive shuttle diplomacy with the message "if you whip up violence, there will be

\footnotetext{
${ }^{1} \mathrm{~A}$ Bantu group found in Kenya.

${ }^{2}$ A Nilotic group found in Kenya.

${ }^{3}$ A Nilotic group found in Kenya

${ }^{4}$ A Bantu group found in Kenya.
} 
consequences" served an important deterrent function. The anti-violence approach employed lexical items and phrases advocating for peace and desisting from violence, and peaceful settlement of disputes took precedence. The lexical items peace, reject intimidation and violence, consequences of violence, court, and come together as a nation replaced inflammatory words (Halakhe, [16]). The lexical items were aimed at pacifying the people and urging them to settle election related disputes in a judicial manner or else face prosecution. There was therefore, a sigh of relief when the 2013 elections ended successfully.

From the foregoing, it is evident that words have power to either foment or avert election-related conflict. On the flip side, the notion of outsiders had been reinforced through lexical choices aimed at manipulating people to perpetrate atrocities. Apparently, the insiders outsiders nexus is fore grounded by competition for power, land and other resources all of which have paved way for ethno-political conflict ingrained in the association of the presidency with the gains to his ethnic constituents (Rutten \&Owuor, [18]). As Cho, et. al., [17] observe, the presidency will remain the ultimate political prize Kenya will pay. This prize has pitted one community against the other in informal urban establishments such as Kibera, Huruma and Mathare in Nairobi, and upcountry in Mombasa, Molo, Naivasha, Uasin Gishu (Tarakwa) and Nyamira (Njogu, [14]; Rutten \& Owuor, [18]).

Tarakwa has particularly been hard-hit by election-related violence since the advent of multi-party election in 1992. In Tarakwa, the Kikuyu and the Kalenjin are dominant speech communities, and they have been a common denominator in election-related violence. However, there was a reversal in the 2013 run up to election when the presidential candidate and his running mate were united by a common case of crime against humanity in the International Criminal Court (ICC). The duo capitalized on their common predicament to call for peaceful election at the same time to prove to the ICC that they were innocent (Jenkins, [9]). It is also in Tarakwa where peace initiatives were first launched to reconcile members of the rival Kalenjin and Kikuyu speech communities (Rutten \& Owuor, [18]). The reviewed studies, have highlighted the role of certain lexical choices made by political elites, religious groups and the media in fomenting or mitigating election-related conflict in different parts of Kenya. The present study focuses on how election-related conflict in Kenya was averted with reference to how the presidential campaign speeches was perceived in Tarakwa. The present study challenges the top-bottom approach of politicians, religious leaders and the media manipulation of the electorate through lexical choices to either engage in violence or maintain peace. With regard to the 2013 election that ended peacefully, the present study takes the contrary position by showing that the electorate can employ their cognitive resources to assess the relevance of peace messages imposed on them. The paper therefore, analyzed the lexico-pragmatic processes of interpreting the term peace employed in the 2013 presidential campaign speeches. The objective of the study was to establish the relevance of the concept peace employed in conflict management in the 2013 Kenyan presidential campaign speeches to the residents of Tarakwa.

\section{Relevance Theory and Lexical Pragmatics}

Relevance theory is a pragmatic theory that focuses on human cognition and communication. Propounded by Sperber and Wilson [19], relevance theory is driven by the central tenet that our mental faculties are oriented towards processing relevant information. In relevance theory, human cognitive system tends to allocate attention and processing resources so as to maximize the relevance of the inputs it processes on one hand (Sperber \& Wilson, [19]). The communicative dimension, on the other hand, stipulates that a speaker's utterances creates general expectations of relevance. This means that the addressee of an utterance is entitled to expect it to be at least relevant enough to be worth processing and the most relevant utterance compatible with the speaker's abilities and preferences (Sperber \& Wilson, [19]). This motivates the following comprehension procedure which is applied to the online processing of attended verbal inputs. The addressee takes the linguistically decoded meaning: following a path of least effort, he enriches it at the explicit level and complements it at implicit level until the resulting interpretation meets his expectation of relevance; at which point, he stops (Wilson, [20]). According to Sperber and Wilson [19], this mutual adjustment of explicit content, contextual assumptions and cognitive effects constrained by expectation of relevance is the central feature of relevance-theoretic pragmatics. Relevance is the trade-off between processing effort and the cognitive effects achieved. 
Relevance theory approach to comprehension has two important consequences to lexico-pragmatics. To start with, Wilson [20] points out that there is no presumption of literalness since the linguistically encoded meaning of a word, a phrase or a sentence is no more than a clue to the speaker's meaning, which is not decoded but non-demonstratively inferred. Second, Wilson [20] adds that understanding any utterance (literal, loose or metaphorical) is a matter of seeing its intended relevance as specified in the relevance-theoretic comprehension procedure. In the example "the water is boiling", boiling refers loosely to a broader concept BOILING to encompass both the normal boiling point of water (99.97 degrees celcius) and a range of somewhat lower temperatures, communicating that the water is very hot and not necessarily boiling (Carston, [21: p157). "Mary is a violet" is a metaphor that is analyzable as a radical extension of linguistically-specified denotation (Wilson, [20]). Violet is broadened to acquire the ad hoc concept VIOLET* representing the category of delicate, unflamboyant, easily overlooked things, of which violets are a salient subcategory (Wilson, [20]). These examples demonstrate that lexico-pragmatic processes are triggered by the search for relevance; they follow a path of least effort, they operate via mutual adjustment of explicit content, context and cognitive effects, and they stop when the expectations of relevance raised by the utterance are satisfied (or abandoned). Wilson [20] exemplifies this account using temperature, which is narrowed in an utterance in which Peter suggests that he and Mary visit his aunt in hospital, and Mary replies:I have a temperature.

Wilson explains that Peter will be expecting Mary's utterance to achieve relevance at that point in the discourse. Mary's utterance literally interpreted is trivially true and achieves no cognitive effects. Wilson [20] adds that temperature, being a scalar term yields different implications when combined with easily accessible contextual assumptions. Peter's encyclopedic assumptions about temperature, hospital visits and the possible connections between them should be highly activated by following a path of least effort in mutual adjustment of content, context and cognitive effects to arrive at an interpretation in which temperature expresses an ad hoc concept TEMPERATURE*, denoting a temperature high enough to make it inadvisable for Mary not to visit Peter's aunt in hospital. In regard to this interpretation, Wilson [20] adds that narrowing is undertaken in the search for relevance as hearers satisfy their expectations of relevance by looking for true implications. Furthermore, a hearer following the relevance-theoretic comprehension procedure narrows the encoded sense to a point where it yields true implications to satisfy general expectations of relevance raised by the utterance, together with any more specific expectations raised by the speaker's utterance for that audience, at that particular point.

To elaborate on narrowing and broadening, Barsalou [22] observes that lexical items give access not only to ready-made prototypes (assigned by default rule) but to a vast array of encyclopeadic information which varies in accessibility from occasion to occasion with different subsets being selected ad hoc to determine the occasion specific interpretation of a word. The construction of ad hoc concepts is affected by context, accessibility of encyclopeadic assumptions and consideration of relevance (Barsalou, [22]) and involves narrowing and/or broadening (Wilson \& Carston, [23]). In narrowing a word conveys a more specific sense than the encoded one, resulting in a restriction of the linguistically-specified denotation as in the example of TEMPERATURE*, while in broadening, the sense becomes broader than the encoded sense as in the example of ROSE* (Wilson, [20]). The ad hoc concepts are capitalized with an asterisk to set them apart from encoded concepts which are italicized.

\section{Materials ANd Methods}

This paper is part of an ongoing $\mathrm{PhD}$ research by Mose which focuses on conflict management in the 2013 Kenyan presidential campaign speeches from the pragmatics standpoint. The study was qualitative and employed analytical research design. The study area was Tarakwa County Assembly Ward in Uasin Gishu County, Kenya, purposively sampled because of its characteristics of being a hot-spot for election-related conflict, and also experiencing relative calm during the 2013 general elections (Uasin Gishu County Integrated Development plan for 2013 to 2018 [24]). The study population were the 37,683 residents of Tarakwa (Uasin Gishu County Integrated Development plan for 2013 to 2018 [24]) and the eight presidential candidates of Kenya in 2013 namely Uhuru Kenyatta of Jubilee Alliance, Raila Odinga of Coalition for Restoration of Democracy (CORD), Musalia Mudavadi of Amani National Congress Coalition, Peter Kenneth of Eagle Alliance, Martha Karua of National Rainbow Coalition (NARC) Kenya, Paul Muite of Safina, James Ole Kiyiapi of Restore and 
Build Kenya and Abduba Dida of Alliance for Real Change (ARK). The population of campaign speeches delivered by the purposively sampled candidates namely Uhuru Kenyatta, Raila Odinga Musalia Mudavadi and Martha Karua between $1^{\text {st }}$ September, 2012 and $2^{\text {nd }}$ March, 2013 when presidential candidates started intensifying their campaigns to the final official campaign day respectively was 150 . This is according to CITIZEN TV, NTV, and UHURUTV that were accessed on the You Tube. 20 speeches delivered by the sampled candidates were also purposively sampled.

Four focus group discussions (FGD) were conducted in Tarakwa. The inclusion criteria required FGD participants to be at least 25 years, residents of Tarakwa from 2007 to 2013 and from the different ethnic groups found in Tarakwa, each with the common characteristics relating to conflict management in 2013 elections. This homogeneity enabled participants to share ideas and participate freely in the discussion, and the researcher to manage the sessions (Jayanth \& Nelson, 2012 [25]). To facilitate the discussions, Kiswahili was used and only participants who spoke Kiswahili or English or both were sampled. The FGD participants watched one campaign speech from each of the four sampled candidates lasting between 4 to 7 minutes. Campaign speeches delivered in Kiswahili were translated into English for purposes of analysis using semantically equivalent terms to cater for semantic loss.

Data was analyzed within the tenets of relevance theory. This paper focused on the theme of peace. Therefore, lexical items relating to the theme including peace, peaceful, calm and rest were studied. With their attention directed to these lexical items, the participants interpreted the utterances aimed at conflict management and commented on their relevance in conflict management in 2013 elections. The presidential candidates' utterances regarding conflict management were the ostensive stimulus or the input of a cognitive process which the FGD participants interpreted. In this paper, the abbreviations PC1, PC2, PC3 and PC4 symbolize the presidential candidates Uhuru, Raila, Mudavadi and Karua respectively. T1, T2, T3 and T4 symbolize the FGD responses from Chagaiya, Kipkurere, Languise and Tarakwa sub-locations respectively and data obtained from the presidential speeches and FGD are numbered sequentially.

\section{RESUlts AND Discussion}

This section presents an analysis of the utterances where the lexical item peace was employed in the 2013 presidential campaign speeches. It begins with a discussion of the concept "peace" as interpreted by FGD participants as reflected in (1), (2) and (3).

1) If people are peaceful, there will be love, unity and development in the country and villages. (T1)

2) It is the election period not to be like the one blood was shed in 2007. It is better for one to lack everything but peace to be there. One can do with hunger in the homestead but without peace there will be problems.

3) All people to stay peacefully. Without war, everybody can develop.

From these observations, in the FGD's encyclopeadic entry, the concept peace postulated a situation in which there is no war. The presence of peace in Kenya surpasses basic requirements such as food. By resorting to the contextual resources derived from the Kenyan elections which have been marred by conflict, regarded in this study as old contextual assumptions, the FGD participants argued that the concept peace also denoted "avoiding bloodshed" and "making people calm". The contextual implications were that peace was an important ingredient for love, unity and development. The utterances encoding the concept peace uttered during the run up to the general elections were important at the point in time they were uttered. Thus, interpreted from this context, the narrowing process of the concept peace was triggered.

Through the adjustment of content, context and cognitive effect, the encoded concept peace was narrowed to express an ad hoc concept PEACE* denoting the need to desist from conflict during the elections. However, having expectations of relevance in what peace can achieve to the individuals, villages and the country, the FGD participants broadened the sense encoded and used it to access other arrays of encyclopeadic assumptions from which they selected love, unity and development as subsets. Constrained by expectations of what peace would lead to, context involving loss of businesses and animosity among people in previous election-related violence the inferential process was activated. Thus, peace also expressed the ad hoc concept PEACE* denoting a broader category 
containing not only literal cases of peace, but other cases that share with it the encyclopeadic attribute of love, unity and development. From the responses, the concept peace was both narrowed and broadened. Wilson [20] notes that narrowing and broadening may combine so that a single word may express an ad hoc concept that is narrowed in some respect and broadened in others

In the presidential campaign speeches, peace was encoded in Kiswahili lexical items such as (amani) peace, (kuwanaamani) be peaceful (tulia) be calm, pumzika(rest). The encoded concept peace was further fine-tuned to suit each utterance. Carston [21] observes that lexical narrowing is a quite flexible process in that the encoded meaning may be narrowed to different degrees and in different directions depending on the particular occasion of use. The presidential candidates' utterances regarding conflict management were the ostensive stimulus or the input of a cognitive process which the FGD participants processed.

\section{Sisiwachana na sisi tunataka amani katika taifa letu.}

Leave us alone. We want peace in our nation.

(PC1)

In relevance theory, utterance interpretation requires a hearer to first determine the propositions explicitly communicated by the speaker. This task involves disambiguation, assignment of referent to indexicals and filling in missing constituents and various other enrichments or adjusting of encoded content (Carston, [21]). In utterance (4), "us" was assigned the referent of the youth of Kenya as deduced from the preceding utterance "You, youth, when a leader tells you to fight...". "Nation" referred to the country Kenya, and "peace" was given the semantic sense of a state of no war. However, given that (4) was articulated at a particular time by the speaker, to complete the proposition expressed, the hearer needed to adjust the unarticulated content in regard to time such as "during the 2013 elections". In (4), PC1 invoked his belief in the inherently peaceful nature of Kenyans. By making mutually manifest the old assumptions in the contextual discourse wale ambao wanataka taabu, hiyo ni yao "Those who want trouble, it is up to them", PC1's contextual assumptions made manifest about violence were activated as being caused by a few individuals, probably leaders, and as something that was anticipated in every election. In the utterance, PC1 also made it explicit that he was telling the youth to desist from leaders who incited them. The FGD participants accessed these assumptions:

4) We fought among ourselves...but these rich people boarded planes with their children and went their ways.

5) He was trying to tell the other politician that they should not use their wealth badly to punish the poor because they have theirs which cannot be destroyed.

The FGD participants accessed assumptions from previous election-related violence made mutually manifest by PC1 in which they underscored the influence of rich politicians who abuse power and wealth to destabilize the poor. Example (4) was ostensively a new assumption which combined with and eliminated the contextual assumptions (5) and (6) accessed by the FGD participants to satisfy the expectation of relevance that if the youth are not incited by rogue politicians, there will be peace. As noted in (1), (2) and (3), the encoded concept peace was narrowed to convey the ad hoc concept PEACE* denoting need to desist from election-related conflict in 2013 elections. In the preceding utterance, PC1 had stated that "If a leader tells you, youth go and fight, tell him to take his wife and children in the battle front". In example (4), the cognitive environment of peace was narrowed to express the ad hoc concept PEACE* to denote averting conflict during the 2013 election. The environment following the lexical item peace "in our country Kenya", led to the implicated conclusion that the concept peace expressed the ad hoc concept PEACE* which includes the need to not only uphold peace during the 2013 elections but also the broader category that when the youth desist incitement there will be no conflict during the elections. To explore the notion of elections and peace in relation to the encoded concept rest and calm, example (7) was considered.

6) Na wakati tunaenda kwa uchaguzi, mimi nataka kuhimiza mKenya pahali popote alipo, wewe piga kura yako uende nyumbani upumzike na utulie.

And as we approach elections, I want to appeal to any Kenyan wherever he is to cast his vote, go home, rest and be calm.

Connecting the underlying assumption of how the 2007/2008 post-election violence erupted, PC1 uttered (7). The encyclopeadic entries of the concept rest and calm were reflected in (9) to (11). 
7) He did not say go and rest as a group. If you stay calm and the other stays calm, there will be no problems.

8) A person should wait for the results and not go around uttering words carelessly that will shake the peace foundation.

9) It is important (to be calm) because after I vote I should go to my place and you also do the same. If we conglomerate, we will argue and cause chaos by saying I voted in person A and you person $B$ instead of voting in this one.

10) These are competing with the others and are saying there will be problems. This shows if they do not win there will be problems. That is why he is bringing in the issue that after casting your votes, go home and be calm.

According to (8), maintaining peace is an individual's responsibility. Being calm and going to the house after voting instead of arguing in the streets and speculating the result (9) and (10), prevents agitations in the event that one's favourite candidate loses in an election. The encoded concept rest and calm were an ordered array of encyclopeadic assumptions including (12) and (13)

11) When results are delayed, doesn't it mean that they are being manipulated? Don't you see there was a problem during Kivuitu's5 time and that sparked violence?

(T1), (T3)

12) The result was announced very fast and they announced the results that Raila did not expect and it made them furious.

13) Delaying results means they are manipulating results in their favour.

The contextual assumptions accessed connected to the encyclopeadic assumptions in (8) to (11). As a result of delaying the result, people became anxious, hence the reason PC1 told people to go home rest and be calm. However, the FGD participants noted when the result for presidential elections in 2007 were delayed, the electoral body officials were manipulating them in favour of one presidential candidate. Samwel Kivuitu in (12) was the chair of the Electoral Commission of Kenya that oversaw the 2007 elections in which presidential results were disputed. The FGD participants attributed the ensuing violence to rigging of elections. The assumptions accessed by the FGD participants explain why when Mwai Kibaki, the third president of Kenya, was declared winner at the dusk of $29^{\text {th }}$ December, 2007, Raila and his supporters contested and violence ensued. Jenkins [9] and Halakhe [16] attribute the 2007/2008 post-election violence to election rigging which PC1 seemed to base his assumptions. From the encyclopeadic knowledge, together with following a path of least effort in the adjustment of content, context and cognitive effect, the FGD participants narrowed the concepts rest and calm to expressed the ad hoc concepts REST* and CALM*. These denoted disengaging with speculations about potential winner after casting the ballot and not taking any violent actions respectively. While acknowledging that calming is essential in fostering peace, they also argued that it may be used to carry out election malpractices in (14). Access to this assumption led to elimination and abandoning of (7) as (15) implies, which triggered another lexico-pragmatic process of interpreting the concept calm.

14) He had already seen that he has qualified so he just urged the people to go home calmly.

First, the contextual assumptions were drawn from the delay of presidential elections results in 2007 that caused anxiety. Next, Kibaki was declared winner. Then the results were contested and mass action ensued. Thus, the concept calm was broadened to contain not only the sense of disengaging with speculations about the winner and maintaining peace but also an advance celebration of presidential victory. The ostensive stimulus or the new assumption in (7) was weakened by the old assumption of how delay of election result triggered violence. Thus, by following a path of least effort in the mutual adjustment of content, context and cognitive effect the concept calm was broadened to contain the category of fostering peace by not speculating result as well as advance celebration of the presidential elections winner. From the FGD response, PC1 exuded confidence about his victory, something that made the participant skeptical about how he would achieve that. Therefore, in (7), calmly did not denote peace but a celebration.

While PC1 urged the electorate to rest and be calm in (7), PC2 in (16) pointed out that the people were peaceful only that they are incited to violence. 
15) As you can see the Kenyan people are very peaceful. Even last time they were very peaceful. (PC2)

The pragmatic process involved in the interpretation of (16) included reference resolution, disambiguation and saturation. It was not quite clear who the referring expression "you" addressed. However, in the next utterance "they" had its antecedent in "the Kenyan people" who PC2 talked about to a third person. "Last time" needed to be made clearer by stating that it referred to the period preceding the announcement of the presidential election results. By stressing "even" PC2 compared the peaceful audiences in 2007 with the one he was addressing in 2013. In the first utterance, the hearers needed to enrich the utterance with an expression like "when they have not been provoked". A further enrichment was "but they can be violent when they are provoked".

As in (1) to (3), the encyclopeadic entry for the encoded concept peaceful was a state in which people were not warring. In example (16) the assumption was that the people were peaceful during the period preceding the elections. Concerning the contextual assumption that foregrounded utterance (16), the FGD participants pointed out the following:

16) The people's reaction only began after releasing the results of the election.

17) Delaying elections results may mean that they (election officials) are tampering with elections.

18) Elections are sensitive in Kenya. Anything touching on election like delaying results, may shake the foundations of peace.

The assumption in (17) shows where and how peaceful existence ended and paved way to violence. Response (18) is a possible cause of what caused the delay while (19) portrays the extent to which elections in Kenya may put peaceful coexistence at stake. These observations auger with Jenkins [9] and Halakhe [16] argument that possible rigging in election triggered violence. Beyond this trigger, however, there was a contention that the Kalenjin had pronounced war against the Kikuyu if Kibaki won as narrated by victims of post-election violence (Njogu, [14]). In these narratives, the Kalenjin expressed displeasure with Kibaki's governance, a contention that supported Yieke [8] views concerning deep-rooted grievances between the two communities. Concerning if the new assumption (16) was relevant in conflict management, the FGD participants argued:

19) It is significant because he did not mention anybody and he was able to calm the citizens because if he had mentioned anybody's name, I think he would have incited citizens.

The concept calm which was narrowed to express the ad hoc concept CALM* to denote need for peace during election was applied in the interpretation of (16) as shown in (20). Based on this it was possible to arrive at a conclusion on which the concept peaceful was narrowed to express the ad hoc concept PEACEFUL* to denote that in 2007 elections, the electorate were peaceful during the period preceding the announcement of presidential results but became violent after the announcement. It also denoted that in 2013 the electorate were inherently peaceful. Looked at this way, the expectations of relevance that the 2013 elections were going to be peaceful were satisfied. In (21), the lexical item "peaceful" was also employed, and the encyclopeadic entries and assumptions of the FGD participants regarding the concept peaceful were the same as those used in the same concept in (16).

20) We will go to the courts and we are urging all our supporters to be peaceful because we are winning the elections.

(PC2)

In utterance (21), the referent "we" referred to PC2 and his co-principals, Kalonzo Musyoka and Moses Wetangula. "Our supporters" meant the people who were going to vote for PC2. The expression "go to the court" was enriched with the constituent "if there will be any election-related anomaly". The context "We will go to the courts" was the immediately preceding utterance of "If there will be any anomalies, we will pass even through the legal channel". When asked to interpret the concept peaceful, the FGD participants observed:

21) He is not sure of winning and if he will win, he feels that rigging will be done the way it was done that day so that if anything happens he will have a claim.

22) Raila had hopes that in this election that was being conducted he would win. He was reflecting back in 2007 on how rigging took place at the KICC. So he is not so confident but still remembers what happened. 
The interpretation of utterance (21) had far-fetched assumptions in which in the 2007 elections, the presidential results were disputed. Instead of seeking court redress, supporters of the two leading presidential candidates, Kibaki and Raila, engaged in violent acts. Therefore, by urging the supporters to be peaceful, PC2 implied that the 2007/2008 post-election violence was triggered by the anomalies in elections as well as failure to seek court redress. Regarding the eruption of violence in 2007, the FGD participants argued that rigging elections was just a trigger. However, there were other farfetched contextual assumptions that set rigging of elections as an outlet of the vengeance the Kalenjin (supporters of Raila) had against the Kikuyu (supporters of Kibaki) as noted in the post-election violence narratives (Njogu, [14]) in concord with FGD participants' observation in (24).

23) The way people were pushed away, the Nandis on this side and the Kipsigis on the other ... when they (Nandi and Kipsigis) came back after the government assumed leadership, it failed to take the land owners back.

Assumption (24) depicts the contentious issue of land which had been one of the underlying causes of election-related violence in Kenya. Lynch [26] argues that many people have feared the Kikuyu and resented the perceived encroachment of Kikuyu onto land that many Kalenjin were displaced from during the colonial period, and never adequately compensated for. In the hearers' encyclopeadic memory, the Kalenjin had rallied behind PC2 in 2007 through whom they saw the opportunity to recover their land.

In (21), the FGD participants observed that PC2's reason for being peaceful was that he and his supporters were confident of a win. This implied that in case they would not win, they will not be peaceful. Thus, the concept peaceful was broadened to express the ad hoc concept PEACEFUL* denoting a broader category of not only being peaceful during the period preceding the announcement of the results, but also the confidence that disputes will be settled as well as maintaining peace if PC2 wins. From utterance (16) and (21), the encoded concept peaceful, was an access point to assumptions derived from the immediate trigger of the 2007/2008 post-election violence which was rigging of the presidential elections from which the appropriate sub-sets were selected. In (25), PC3, made mutually manifest the contextual assumption that in the past, deaths had occurred during a past election.

\section{4) Tunataka jina letu ambalo ni Amani Coalition lifanye kazi katika mambo ya uchaguzi ili damu isimwagike kamwe kama ilivyomwagika wakati ule. \\ (PC3)}

We want our name which is Amani Coalition to work in election issues so that blood will not spill at all the way it spilt that time. (PC3)

In (25), "we" referred to PC3, his running mate and other party supporters. The expression "our name" was made clearer to specifically mean the name of the party that sponsored the speaker which was Amani National Coalition. Next, the vague expression "to work in election issues" needed a clarification such as the word "Amani" means peace, so it should reflect the party members as champions of peace during 2013 Kenyan election campaigns. More enrichment regarding the need for peace was also done by bringing to the fore the aftermath of the 2007 elections which ended up in violence. This was meant to justify the subordinate clause "so that..." in which blood referred to death. Regarding the interpretation of the concept peace, the FGD participant observed:

25) He is telling the rest to use his party's name in the elections to prevent a replication of what happened in the previous elections.

26) The name Amani makes people calm and vote peacefully.

Utterance (5) displayed the flexibility and creativity of the mind, in that it can construct and use new concepts at a moment's notice (Wilson, [20]). In (26), the FGD participants argued that PC3 used his party's name Amani "peace" to prevent violence in elections. In (26), the FGD participants argued that the name Amani, a party name, had the potential to calm people and make them vote peacefully. This went beyond the literal meaning of absence of war. From FGD responses on (26) and (27), the sense encoded by the concept peace was broadened to express the ad hoc concept PEACE* to not only denote his party's name, but also its ability to prevent violence in the 2013 elections as well as compel people to be calm and vote peacefully. PC3's creativity in the use of the concept amani "peace" was also reflected in example (28). 
27) Wale wengine, wanasiasa wa mrengo mwingine wakija kwa mkutano wanasema muishi kwa amani. Wakimaliza mkutano wanasema mwende nyumbani kwa amani. Wakisema mpige kura, wanasema mpige kura kwa amani. Sasa ikiwa wananifanyia kampeni kwa sababu wanasema mpige kura kwa amani.... Si wanasema piga kura kwa amani. Amani ni nani?

Those others from the other coalitions, when they come to the meeting they say live inpeace. When they finish the meeting they say go home in peace. When they say vote, they say vote in peace. Now, if they are campaigning for me because they are saying vote in peace.... Aren't they saying vote for peace. Who is peace?

(PC3)

Concerning (28), the FGD participants' interpretation of the utterance involved resolving the reference "those others" and "they". They also disambiguated the phrase "other coalitions as well as assigning the concept peace an ad hoc concept.

28) He talked about Jubilee and CORD because those are parties that have people.

The hearers' encyclopeadic assumptions about peace, coalitions, meeting, go home in peace and the connections between them were activated. Based on the manifestation of "those others, from other coalitions" being the competitors of PC3, the FGD participants indicated that the reference referred to Jubilee and Coalition for Restoration of Democracy (CORD). From these, it was a straight forward matter to link the coalitions with their candidates: PC1 and PC2 respectively. This reference was made clearer when, in another discourse, PC3 indicated that he would use cold water to calm the two "I will take cold water and pour on Jubilee... CORD..." The encyclopedic memories PC3 was activating compared to the observations Michira (2014) made about the age old enmity between the fathers of these two leaders, Jomo Kenyatta and Oginga Odinga, who were once president and vice president of Kenya respectively, and which has trickled down to their sons. The contextual implication of PC3's utterance was that Kenya needed a neutral presidential candidate. By capitalizing on the indirect campaign opportunity his coalition name offered him, PC3 admitted that PC1 and PC2 were appealing to the people to maintain peace.

The FGD participants' interpretations of the concept peace in (29) was as in (30) and (31):

29) It is not Amani, the coalition the others (PC1 and PC2) were saying. He meant the peace of Jesus, the usual peace. He was fooling the citizens.

30) He was campaigning for himself.

In this observation, it emerges the FGD participants' interpretation of the concept peace as absence of violence in the election was abandoned as it lacked the encyclopeadic entries they had attributed to it in (1) to (3). They observed that PC3 was exploiting his creativity by playing with words and was therefore ironical. Though he appeared to champion for peace, it was apparent that he was using humour to campaign for himself while discrediting his opponents. In doing this, it also emerged that conflict management in the 2013 elections largely depended on PC1 and PC2. PC3's speech brought out the deep rooted rivalry between the two and it was in order to urge Kenyans to uphold peace as they wait for a lasting solution.

The fact that PC1's and PC2's campaign speeches were dominated by peace messages as confessed by PC3 was an indication that these two used their positions to urge their supporters to desist from violence. However, the FGD participants' expectations of relevance in this presumption was abandoned. To start with, the FGD participants observed that the assumption "if the two meet in a corner, no one will leave the other" in the contextual discourse weakened the ostensive stimulus in (28) paving way for the implicated conclusion that violence was inevitable. Second, as stated by the FGD participants, the peace messages in PC3's speech did not denote averting conflict during elections, but to play with words as one participant said "he was campaigning for himself". The encoded concept peace was thus broadened to express the ad hoc concept PEACE* denoting not only PC3's quest for peace during the campaigns and after the elections but also the way PC1 and PC2 appealed to voters not to engage in conflict and how these two also unknowingly wooed voters to vote for PC3.

The issue of incitement of voters by leaders was revisited by PC4 in (32):

31) Kila kiongozi, kila mKenya tuko na jukumu la kuwaambia waKenya tukae na amani sababu mkifanya incitement niwanyonge wanawachiliwa wagongane. 
Every leader, every Kenyan, we have the responsibility of telling Kenyans to be peaceful because if you do incitement it is the poorthat clash.

(PC4)

In (32), "every leader" referred to the politicians vying for elective positions in Kenya. The referent "we" refered to the speaker, PC4, the leaders and all Kenyans. The reference "you" meant the politicians. The hearers also enriched the unarticulated content "to be peaceful during the 2013 elections by not telling the poor to cause violence. The FGD respondent noted:

32) She said that if you will not be peaceful you will only be hurting yourselves. The poor people without anything fight because of the little campaign money.

In (32), the ostensive stimulus derived contextual assumptions from the 2007/2008 post-election violence as the FGD participants indicated in (33). In (33), the participants indicated that people who were killed or displaced and their property destroyed in 2007/2008 PEV were the poor. From the FGD participants' observation, not being peaceful, leads to people hurting themselves. In addition, accepting bribery leads to violence. Halakhe [16] confirms that as Kenya approached 2013 elections there were risks of violence and mass atrocities which were weakened by the new assumptions PC4 put forth urging people to refuse bribes. The concept peaceful in this example was therefore narrowed to express the ad hoc concept PEACEFUL* denoting that the people should be peaceful during the 2013 elections to avoid violence. In (34), the sense encoded by the concept peaceful was broadened.

33) Nauliza kila county waKenya waamue tunataka amani ndivyo tuweze kila mtu kujitafutia.

I am asking every county to decide we want peace so that we can everyone fend for themselves. (PC4)

In (34), "I" referred to Karua, while "every county" referred to "the people from all counties of Kenya. The expression "to decide we want peace" was further enriched to specify the time peace was needed and the consequence of peace which was "to decide we want peace during the 2013 elections in Kenya. The reason for fending for themselves in the subordinate clause needed a justification such as when people are fighting, we cannot work. Concerning (34), the FGD participants argued:

34) Peace is important .... It means a person should be free to do what they want, even if he sleeps in the trenches it is up to them.

In (34), the new assumption by PC4 was that peace was a precursor for people to work. In interpreting the utterance, the FGD participants underscored this fact and added that peace gave people freedom to do as they wished. In (34), the encoded concept peace expressed the ad hoc concept PEACE* narrowed to denote not only the need for the weak or poor to uphold peace during the impending elections as they were the most vulnerable to violence. In (35), the concept peace was broadened to express the ad hoc concept PEACE* denoting not only the need to uphold peace during elections, but also peace gave people freedom to do as they wished. PEACE* also enabled people to do productive work if they voted peacefully.

\section{Conclusion}

The theme "peace", focused in this paper, was expressed in lexical items including "peace", "peaceful", "calm" and "rest" in the 2013 Kenyan presidential campaign speeches regarding conflict management. These linguistically encoded concepts were either narrowed, broadened or both. The concept peace was narrowed to convey the need to desist from violence as well as incitement to cause violence from politicians in the 2013 Kenyan elections. Given that previous election-related violence had far-reaching negative impacts on the socio-economic aspects of lives, the concept peace was broadened and equated to love, unity, freedom to do as one wishes and individual development. The narrowed sense of the concept peaceful conveyed inherently peaceful nature of Kenyans. However, it was broadened to include the sense that the presidential candidate had confidence in the just settlement of any dispute by the court. Arguments in the centres and streets concerning potential winner can lead to violence. The concept rest was therefore, narrowed to denote need for voters to disengage with such debates but wait for results in their houses. The concept calm was narrowed to denote the sense of not taking part in any violent acts. 
The interpretation of "peace" elucidated contextual assumptions derived from past election-related violence including incitement from leaders, bloodshed, displacement of people and property loss. This proves that discussions about peace cannot be delinked from violence (Burnes, [7]). In addition, the trade-off between processing effort and the cognitive effects achieved in interpreting utterances in these cognitive environment amounted to the relevance of the use of the concept peace. Owing to this, it is apparent that expectations of peace raised by the utterances were satisfied. However, these expectations were also abandoned as the interpretation of the concept revealed that the candidates were not concerned with peace as discussed before. Rather, peace depended on the victory of the candidate. This implied that in case of defeat, there could be violence. Peace also denoted a presidential candidate's party's name "Amani" which the candidate used to campaign for himself as well as humorously convince voters that other candidates were also campaigning for him. In conclusion, though the lexical items "peace" employed in presidential campaign speeches regarding conflict management was relevant in some ways, it was irrelevant in others. Hence the contention that 2013 elections were peaceful is questioned which proves Lynch [26] assertion that the peace was superficial and cosmetics. In Galtung's [27] words, what resulted was negative peace characterized by absence of violence, pessimism and peace not by peaceful means. As the residents of Tarakwa put it there was no violence but deeply ingrained hatred among the communities living in Tarakwa.

\section{ACKNOWLEDGEMENT}

This publication was made possible by support from the Social Science Research Council's Next Generation Social Science in Africa Fellowship, with funds partially provided by Carnegie Corporation of New York.

\section{REFERENCES}

[1] Thomas, L. \& Wareing, S. (1999). Language, society and power: An introduction. London: Routledge.

[2] Haegeman, L. (1991). Introduction to government and binding theory. (2 ${ }^{\text {nd }}$ Ed.). Oxford: Blackwell Publishers.

[3] Huddlestone, R.(1984). Introduction to the grammar of English. Cambridge: Cambridge University Press.

[4] Crystal, D. (1995). The Cambridge encyclopedia of the English language. Cambridge: Cambridge University Press.

[5] Persuad, G. \& Turner, T. (2007) Education and conflict resolution for democratization: Economic development and governance in Guyana. In C. H., Grant \& R. M, Kurton(Eds.) Governance, conflict analysis and conflict resolution (pp.417-435). Jamaica: Ian Randle Publishers.

[6] Shinar, D. (2003). The peace process in cultural conflict: The role of the media. Conflict and communication online. 2(1) 1-10.

[7] Burnes, S. (2011). Metaphors of conflict in press reports of elections. Studies in variation and change in English. Volume 7. Http://helsinki.fi/varieng/series/volume/07/ Retrieved on $13^{\text {th }}$ September, 2015.

[8] Yieke, F. (2008). The discursive construction of ethnicity: The case of the 2007 Kenyan general election. Codesria $12^{\text {th }}$ General Assembly. Governing the African public sphere. http://www. codesria.org/IMG/pdf/Felicia_A__Yieke.pdf?1282/. Retrieved on 15 ${ }^{\text {th }}$ August, 2015.

[9] Jenkins, S. (2012). Ethnicity, violence, and the immigrant-guest metaphor in Kenya. African affairs. 111: 575-576.

[10] Owino, C. O. (2013). Socio-economic status of the youth in Kenya: Implications for peaceful elections. K. Njogu. (Ed.) Youth and peaceful elections in Kenya. African Books Collective. pp. 55-68).https://books.google.co.ke/books?id=5w2vgDhWP.election.related+violence+ definition Retrieved on $18^{\text {th }}$ February, 2017.

[11] Hirsch, S. F. (2009). Putting hate speech in context: Observations of speech, power \& violence in Kenya. George Mason University. http://www.scgr.gmu.edu.publication.roster.

Retrieved on $5^{\text {th }}$ August, 2016. 
[12] Siele, V. K. (2015). Coded language as a source of ethnic conflict in Africa: A case study of Kenya. (M. A Thesis) University of Nairobi.

[13] Michira, J. N. (2014). The language of politics: A CDA of the 2013 Kenyan presidential campaign discourse. International Journal of Education and Research. 2 (1) 1-18.

[14] Njogu, K. (Ed) (2009). Healing the wound: Personal narratives about the 2007 post-election violence. Nairobi: Twaweza Communications.

[15] Ojwang', B. O. (2009). The semantics of peace and the role of the print media in the 2007 2008post- election violence in Kenya. African Media Review. 17(1\&2) 23-50. https://www. codesria.org/IMD/pdf/3-ojwang.pdf?2581/ Retrieved on 30 ${ }^{\text {th }}$ September, 2016

[16] Halakhe, A. B. (2013). "R2P in practice" ethnic violence, elections and atrocity prevention in Kenya. Global Centre for responsibility to protect. Occasional paper series.

[17] Cho, Y. S. Connors, E. Fatima, F \&Yalim, U. (2015). Preventing post-election violence based on the Kenyan experience. Department of State: United States of America.

[18] Rutten, M \&Owuor, S. (2010). Weapons of mass destruction: Land, ethnicity and the 2007 elections in Kenya. In Kagwanja, P. \& R. Southal. New York: Institute of Social and Economic Research.

[19] Sperber, D. \& Wilson, D. (1995). Relevance: Communication \& cognition. (2 ${ }^{\text {nd }}$ Ed). Oxford: Blackwell.

[20] Wilson, D. (2003). Relevance and lexical pragmatics. Paper presented at the European society for philosophy and psychology and the International Pragmatics Association.

[21] Carston, R. (2010). Lexical pragmatics, ad hoc concepts and metaphor: a relevance theory perspective. Italian journal of Linguisics 22(1) 153-180. http://www.Linguistica.sns.it/ RdL/22.1/carston.pdf. Retrieved on $12^{\text {th }}$ May, 2016.

[22] Barsalou, L. (1987). The instability of graded structure: Implications for the nature of concepts. In U. Neisser (ed.) Concepts and Conceptual Development: Ecological and intellectual factors in categorization. Cambridge: Cambridge University Press. (pp 101-140).

[23] Wilson, D. \& Carston, R (2007). A unitary approach to lexical pragmatics: Relevance, inference and ad hoc concepts. In N. Burton-Roberts (Ed.) Pragmatics. (pp.230-259). London: Palgrave. http://www.phon.ucl.ac.uk/home/deirdre/index3.html. Retrieved on $12^{\text {th }}$ May, 2016.

[24] Uasin Gishu County Integrated Plan 2013-2018. (2013). http://www.Kenyampya.com. userfiles. pdf. Retrieved on $15^{\text {th }}$ September, 2014

[25] Jayanth, M. \& Nelson, J. (2002). Savvy Decision Making: An Administrators guide to using focus groups in schools. California: Corwin Press. Inc.

[26] Lynch, G. (2014). Electing the 'alliance of the accused': the success of the Jubilee Alliance in Kenya's Rift Valley. Journal of Easter African Studies. 8(1) 93-114.

[27] Galtung, J. (1967). Theories of peace: A synthetic approach to peace thinking. International Peace Research Institute. http://www.transend.org/.../Galtung_Book_unpub_theories _of_pea ce_pdf. Retrieved on $5^{\text {th }}$ August, 2016.

[28] UHURUTV. 2013 January, $23^{\text {rd }}$. http://www.youtube.com/watch?v=sY6mLAAQXo.

[29] NTV. 2013, March, $2^{\text {nd }}$. http://www.youtube.com/watch?=33AetRn2J38.

[30] NTV. 2013, February, 26 http://www. youtube.com/watch?v=QFbB7KuzcOQ.

[31] CITIZEN TV. 2012, December, $8^{\text {th }}$. http://www.youtube.com/watch?v=dvhsxbokfOY. Crystal, D. (1995). The Cambridge encyclopedia of the English language. Cambridge: Cambridge University Press. 


\section{APPendix: 2013 KenYan Presidential Candidates' SPeEches}

\section{PC1 Speech}

How are you!

We as Jubilee members, our first aim is to ensure that we have brought peace in our nation of Kenya. Secondly, to ensure we have unity of all Kenyans so that together we can expand our economy. And we should ensure that every Kenyan wherever he is he is proud of his nation. Our fellows, us, our politics are not of insults. We know that the youth are the majority in our nation of Kenya, and when they are many, we want a government that will serve them, but not to use them the way the youth have been used badly in the past.

Our fellows, we know that as leaders if we cooperate, and say that there is no hatred among us and we will not put hatred on the assets of the citizens of Kenya. It is a lot we will achieve. Our fellows, we want to ensure that we have dealt with poverty in our nation of Kenya.

The thing that has spoilt our country is the politics of quarrels and politics of hatred. We have said that those are over, because our fellows those politics are the ones that have brought poverty in our nation of Kenya. Leaders are seeking trouble but do not care about the welfare of the ordinary citizens of this republic of Kenya. Our fellows we want a change.

Therefore, our fellows when we are here we want to say, when we are here tribal politics to end. We want now to have politics that all of us we will discover ourselves as Kenyans knowing that problems are problems and do not know tribes. And I am telling you this, my fellows, there are those who would have liked to name Kenya this tribe this tribe but I know that the blood that circulates among us all is red. When you go to the hospital, does the doctor ask you your tribe before treating you? Please my fellows, let us stop those tribal politics.

We unite as Kenyans, we dialogue as Kenyans and I have no doubt if we do that we will achieve many good things for our nation of Kenya.

As I come to the end, my fellows I want to tell you one thing. It is said that there will be trouble in this Kenya of ours when elections come. Do you believe that? I want to say this, those who want trouble it is up to them. We know that Kenyans are for peace. And as we are going for elections I want to urge any Kenyan wherever he is, you cast your vote, go home, rest and be calm. There is no need for war. The vote is the one that will decide. What will the vote do? The vote is the one that will decide. If a leader tries to tell you, "You, youth, go fight". You tell him "take you children and your wife to go to the battle front. Leave us alone, we want peace in our nation".

And I know, if we do this our fellows, because that is the objective of Jubilee alliance, we want to ensure that the economy moves from being and economy that is run from the top, but rather one that is run from the grassroots. We want to know that our success will not be based on whether our economy has grown by 12 or $13 \%$ but by the way we have reduced poverty.

I want to assure you that our alliance has united Kenyans from every place, every corner of our republic of Kenya. Our alliance has united old men, it has united the youth, and mostly, it has united women....

\section{UHURUTV [28]}

\section{PC2 Speech}

We want ninety-minute match. No extra time, no extra time. We are saying we want peace. We want peaceful elections. And we said, if we are defeated we will concede defeat. I know we will not be defeated. But if we will be defeated, we will concede defeat.

We are resting our case today. We are saying that we are finishing today here. Monday. Thirty - six hours are remaining. The match will be for the citizens now. The citizens have remained with the match to play on Monday and we want ninety-minute match. No extra time.

As you can see, the Kenyan people are peaceful. Even last time, they were very peaceful. They were only provoked through the rigging that took place at the KICC. 
We hope and we hope that there will be no rigging this time. As CORD Coalition, we have given you the undertaking that we will respect the outcome of these elections. We have said that in the unlikely event that we are defeated we will accept the results. If there is any anomalies we will pass even through the legal channel. We will go to the courts and we are urging all our supports to be peaceful because we are winning the elections. Every Kenyan with1 a vote, whether old, lame, sick to be carried and be taken to cast a vote.

NTV [29]

\section{PC3 Speech}

Those who grow flowers here, here at Timau, where do those flowers go? Those who grow coffee, where does the coffee go? The tea leaves that is near this place, where does it go?

And when those many tourists come here, where do they come from? If someone says that we have no use of other countries, where will he want you to sell your coffee? We want our name which is Amani Coalition to work in election issues so that blood will not pour at all as it poured that time.

Our brothers are seeking votes. They are seeking votes. But sometimes if you look at politics, if you look at the way they are looking at each other, you would see that if they meet in a corner at night, may be one will not leave the other. So I am saying watch me properly. If Jubilee is burning on this side, if CORD burning on this side, I have cold water I will pour on Jubilee, I will pour on CORD to calm. Then, us as Amani, we drive and bring you together.

\section{NTV [30]}

\section{PC4 Speech}

The issue of unity so that we can be one community is very important. You saw during post-election violence many people were evicted and here a number of people from these two counties of yours, were second to be driven away, with people from Central being number one. But who was evicted? Let us say the truth. It is not the rich people from these communities. It is the helpless. Even where they were evicted, there are still rich people from these two communities who have what? Land. If your land is big, it is as if when the people are told to cause destruction, it is as if we are shaken by the wealth. The rich person was left the way he is. The poor person with a house he built with difficulty, because he sweated so much to find the two or three iron sheets he put on the roof. Even the things he has in the house do not cost much, but those are his things in this world. He does not have others. That is the one whose things were burnt.

The one with a house and a lot of wealth and money in the bank such that if his home is touched he will build another, that was not touched. And what unity if the cattle a person sees at a neighbours' place has not been returned? Every leader, every Kenyan, we have a responsibility of telling Kenyans to stay peacefully because if you cause incitement, it is the poor who fight among themselves. Leaders look and see that it is a movie they are watching. You people of Nyamira County, the youth of Nyamira, if you say in Nyamira there will be peace and there will be no violence of any type, that is how it will be. Therefore, I am asking every county, Kenyans to decide. We want peace so that we can, each person, fend for himself. If we depend on the one that is brought during elections, we will eat it in one day or two days, and five years which is one thousand eight hundred and about fifty days, you will suffer because you do not eat the campaign money. You depend on the sweat of your hands.

CITIZEN [31] 